\title{
Factors Associated with Personal Hygiene, use of Personal Protective Equipment, and the Risk of Contact Dermatitis among Scavengers: A Path Analysis Evidence from Surakarta, Central Java
}

\author{
Niken Kartika Sari'), Setyo Sri Rahardjo²), Vitri Widyaningsih²) \\ 1)Masters Program in Public Health, Universitas Sebelas Maret \\ 2)Faculty of Medicine, Universitas Sebelas Maret
}

\begin{abstract}
Background: Scavengers with poor personal hygiene and do not use complete personal protective equipment (PPE) are at risk of developing contact dermatitis. This study aimed to analyze factors associated with personal hygiene, use of personal protectif equipment, and the risk of contact dermatitis among scavengers using path analysis and health belief model.

Subjects and Method: This was an analytic observational study with a cross sectional design. The study was conducted at Putri Cempo landfill, Surakarta, Central Java. A sample of 203 scavengers was selected by total sampling. The dependent variable was contact dermatitis. The independent variables were personal hygiene, PPE, perceived susceptibility, perceived severity, perceived benefit, self-efficacy, cues to action, social support, education, and age. The data were collected by questionnaire and analyzed by path analysis.

Results: The risk of contact dermatitis was directly and positively affected by poor individual hygiene $(b=4.58 ; 95 \% \mathrm{CI}=1.42$ to $3.55 ; \mathrm{p}<0.001)$ and incomplete $\mathrm{PPE}(\mathrm{b}=5.52 ; 95 \% \mathrm{CI}=2.38$ to 5.01; $\mathrm{p}<0.001)$. The risk of contact dermatitis was indirectly affected by and ages 15-35 years, perceived benefit, cues to action, self-efficacy, perceived susceptibility, perceived severity, low education, and social support.

Conclusion: The risk of contact dermatitis is directly and positively affected by poor individual hygiene and incomplete PPE. The risk of contact dermatitis is indirectly affected by and ages 15-35 years, perceived benefit, cues to action, self-efficacy, perceived susceptibility, perceived severity, low education, and social support.
\end{abstract}

Keywords: personal protective equipment, contact dermatitis, personal hygiene, health belief model, path analysis

\section{Correspondence:}

Niken Kartika Sari. Masters Program in Public Health, Universitas Sebelas Maret. Jl. Ir. Sutami 36A, Surakarta 57126, Central Java. Email: knikenkartika@gmail.com. Mobile: 085229509061.

\section{BACKGROUND}

$\overline{\text { Scavengers make a living by collecting con- }}$ sumable materials and turning them into economic value goods by recycling. Final Place (TPA) is one of the scavenger work targets. Scavengers are at risk of developing skin diseases caused by exposure in the work environment. The most common type of skin disease suffered by workers including scavengers is contact dermatitis by
80\% (Nyathi et al., 2018; Carder et al., 2017)

Contact dermatitis is an inflammatory condition because it comes in contact with hazardous chemicals combined with general waste. The national prevalence for dermatitis is $6.8 \%$. Epidemiological studies in Indonesia show that $97 \%$ of 389 occupational dermatoses are contact dermatitis, $66.3 \%$ are irritant contact dermatitis and $33.7 \%$ are allergic contact dermatitis. The 
prevalence of contact dermatitis in Central Java is 7.95\% (Silvestre and Reis, 2018; Suryani et al., 2017).

Surakarta is one of the cities that has increased in its population, resulting in an increase in the amount of waste production. According to data from the Surakarta City Sanitation and Parks Department in 2017, it is estimated that an average of around 291 tons of waste is produced every day. This means that on average in the year 106,279 tons of garbage are produced by Surakarta City. The waste is transported to Putri Cempo Mojosongo TPA, Jebres Subdistrict, Surakarta City (Department of Environment, 2018).

Scavengers need to use and equip personal protective equipment (PPE) when working to protect against the risk of disease. Minister of Manpower and Transmigration Regulation No. 1 Article 1 states that workers must use PPE to isolate the body from potential hazards in the workplace. PPE scavengers include head protectors, hand protectors, body armor and leg protectors. Scavengers who do not use PPE 63.4\% experience contact dermatitis. (Permenker, 2010; Zolnikov et al., 2018; Pardiansyah, 2015; Bhoyrul et al., 2019).

Poor personal hygiene can affect contact dermatitis. Personal hygiene is an effort to enhance the degree of his own health by cleaning all members of the body as prevention of diseases including skin hygiene, foot, nail and hand hygiene, cleanliness of clothing and cleanliness of PPE (Campbell et al., 2017; Aunger et al., 2016; Nivianingrum and Mulasari, 2017).

A preliminary study conducted at Putri Cempo TPA, authors found several scavengers who do not use PPE. Authors also found complaints of skin diseases in scavengers because of contact with garbage. This can be influenced by various factors including the behavior of pemlung to per- form personal hygiene, the use of PPE, perceptions of scavengers related to the benefits of personal hygiene and APD, the originator of the action of implementing individual hygiene and using PPE, self-efficacy of implementing individual hygiene and using PPE, social support implementing individual hygiene and using PPE, perception of vulnerability, perception of severity, education, and age.

This study aims to analyze waste collectors in the implementation of personal hygiene and the use of PPE to the risk of contact dermatitis in the TPA Putri Cempo Surakarta City associated with the theory of health belief model (HBM).

\section{SUBJECTS AND METHOD \\ a. Study Design \\ This was an analytic observational study with a cross sectional design. The study was conducted at Putri Cempo landfill, in Sura- karta, in March until April 2019.}

\section{b. Population and Samples}

The accessible population of this study was all scavengers (207) in TPA Putri Cempo. A sample of 203 scavengers aged 15 to 65 years was selected by total sampling.

\section{c. Study Variables}

The dependent variable was contact dermatitis. The independent variables were age, education, personal hygiene, perceived benefit, perceived susceptibility, perceived severity, self-efficacy, cues to action, and social support.

\section{d. Operational Definition of Variables} Personal hygiene was an effort to enhance the degree of his health by cleaning all members of the body as disease prevention. Data collection was carried out using a questionnaire. The measurement scale was was dichotomous.

Perceived benefit was health behavior that is influenced by scavenger's perceptions about the benefits of doing personal 
Journal of Health Promotion and Behavior (2019), 4(3): 198-211

https://doi.org/10.26911/thejhpb.2019.04.03.05

hygiene and using PPE when compared to the risk of contact dermatitis. Data collection was carried out using a questionnaire. The measurement scale was dichotomous.

Cues to action was social and environmental influences to trigger the decision making process to carry out individual hygiene and use PPE. Data collection was carried out using a questionnaire. The measurement scale was dichotomous.

Self-efficacy was a belief in one's own ability to control motivation, behavior, and social environment in implementing personal hygiene and using PPE. Data collection was carried out using a questionnaire. The measurement scale was dichotomous.

Social support was the availability of resources that provide physical and psychological comfort obtained through the knowledge that he is loved by others so that he supports personal hygiene and uses PPE. Data collection was carried out using a questionnaire. The measurement scale was dichotomous.

Perceived susceptibility was the subjective perception of a scavenger about the possible risk of having contact dermatitis. Data collection was carried out using a questionnaire. The measurement scale is a dichotomous.

Perceived severity was the perception of the severity of contact dermatitis according to the circumstances that might occur. Data collection was carried out using a questionnaire. The measurement scale was dichotomous.

Personal protective equipment use is a device to protect someone whose function is to isolate the body from potential hazards in the workplace. Criteria for PPE scavengers include head protectors, hand protectors, body armor, and leg protectors. Data collection was carried out using a questionnaire. The measurement scale is a dichotomy.
Age was the age of the subject when doing research based on the criteria of date of birth and year of birth. Data collection was carried out using a questionnaire. The measurement scale is a dichotomy.

Education was a formal education that has ever been undertaken by subjects, based on the last diploma held ranging from elementary, junior high school or senior high school level. Data collection was carried out using a questionnaire. The measurement scale was dichotomous.

Contact dermatitis was an inflammatory reaction of the skin due to direct contact with dangerous agents, causing the phenolmenon of sensitization or toxic. Data collection was carried out using questionnaires, case photos and was consulted with Eko Irwanto, dr. Sp.KK to establish a diagnosis. The measurement scale was categorical.

\section{e. Data Analysis}

Univariate analysis illustrates the characteristics of variables based on research results. Bivariate analysis in the study was conducted to determine the effect between independent variables with the dependent variable using the chi-square test. Multivariate analysis was performed using path analysis to determine the magnitude of the effect directly or indirectly on a variable.

\section{f. Research Ethics}

The research ethics in this study included the consent sheet, anonymity, confidentiality, and ethical eligibility. Ethical eligibility in this study came from the Health Research Ethics Committee of Dr. Moewardi Hospital Surakarta with number: 251 / III / HREC / 2019.

\section{RESULTS}

\section{Sample Characteristics}

Table 1 shows the sample characteristics using categorical data. 
Table 1. Sample Characteristics (dichotomous data)

\begin{tabular}{|c|c|c|}
\hline Characteristics & $\mathbf{N}$ & \% \\
\hline \multicolumn{3}{|l|}{ Personal Hygiene } \\
\hline Not good & 50 & 24.6 \\
\hline Good & 153 & $75 \cdot 4$ \\
\hline \multicolumn{3}{|c|}{$\begin{array}{l}\text { Perceived benefit (personal } \\
\text { hygiene) }\end{array}$} \\
\hline Low & 50 & 24.6 \\
\hline High & 153 & 75.4 \\
\hline \multicolumn{3}{|l|}{ Self-Efficacy } \\
\hline Low & 61 & 30 \\
\hline High & 142 & 70 \\
\hline \multicolumn{3}{|c|}{ Cues to action ( personal hygiene) } \\
\hline Low & 66 & 32.5 \\
\hline High & 137 & 67.5 \\
\hline \multicolumn{3}{|l|}{ Social Support } \\
\hline Low & 154 & 75.9 \\
\hline High & 49 & 24.1 \\
\hline \multicolumn{3}{|c|}{ Perceived susceptibility } \\
\hline Low & 65 & 32 \\
\hline High & 138 & 68 \\
\hline \multicolumn{3}{|l|}{ Perceived severity } \\
\hline Low & 61 & 30 \\
\hline High & 142 & 70 \\
\hline \multicolumn{3}{|l|}{ PPE use } \\
\hline Incomplete & 67 & 33 \\
\hline Complete & 136 & 67 \\
\hline \multicolumn{3}{|c|}{ Perceived benefit (PPE use) } \\
\hline Low & 68 & 33.5 \\
\hline High & 135 & 66.5 \\
\hline \multicolumn{3}{|l|}{ Self-Efficacy } \\
\hline Low & 68 & 33.5 \\
\hline High & 135 & 66.5 \\
\hline \multicolumn{3}{|c|}{ Cues to action (PPE use) } \\
\hline Low & 70 & 34.5 \\
\hline High & 133 & 65.5 \\
\hline \multicolumn{3}{|l|}{ Social support } \\
\hline Low & 127 & 62.6 \\
\hline High & 76 & 37.4 \\
\hline \multicolumn{3}{|l|}{ Contact dermatitis } \\
\hline Not experiencing & 157 & $77 \cdot 3$ \\
\hline Experiencing & 46 & 22.7 \\
\hline \multicolumn{3}{|l|}{ Education } \\
\hline$<$ Junior high school & 90 & 44.3 \\
\hline$\geq$ Junior high school & 113 & 55.7 \\
\hline \multicolumn{3}{|l|}{ Age (Year) } \\
\hline $15-35$ & 64 & 31.5 \\
\hline $36-65$ & 139 & 68.5 \\
\hline
\end{tabular}

\section{Bivariate Analysis}

Table 2 showed the resuts of bivariate analysis. Table 2 shows that the risk of contact dermatitis decreased with with poor personal hygiene $(\mathrm{OR}=0.03 ; \mathrm{p}<0.001)$, low perceived benefit, poor personal hygiene $(\mathrm{OR}=0.04 ; \mathrm{p}<0.001)$, low cues to action $(\mathrm{OR}=0.10 ; \mathrm{p}<0.001)$, weak self-efficacy $(\mathrm{OR}=0.04 ; \mathrm{p}<0.001)$, weak social support $(\mathrm{OR}=0.16 ; \mathrm{p}<0.001)$, and low perceived 
Journal of Health Promotion and Behavior (2019), 4(3): 198-211

https://doi.org/10.26911/thejhpb.2019.04.03.05

susceptibility $(\mathrm{OR}=0.02 ; \mathrm{p}=0.001)$, perceived severity $(\mathrm{OR}=0.07 ; \mathrm{p}<0.001)$, incomplete PPE $(\mathrm{OR}=0.01 ; \mathrm{p}<0.001)$, low perceived benefit $(\mathrm{OR}=0.06 ; \mathrm{p}<0.001)$, low cued to action $(\mathrm{OR}=0.06 ; \mathrm{p}<0.001)$,

Table 2. The results of bivariate analysis low self-efficacy $(\mathrm{OR}=0.05 ; \mathrm{p}<0.001)$, low social support $(\mathrm{OR}=0.11 ; \mathrm{p}<0.001)$, low education $(\mathrm{OR}=0.19 ; \mathrm{p}<0.001)$, and age 15 -35 years $(\mathrm{OR}=0.24 ; \mathrm{p}<0.001)$.

\begin{tabular}{|c|c|c|c|c|c|c|}
\hline \multirow[t]{2}{*}{ Independent Variable } & \multicolumn{2}{|c|}{ Dermatitis } & \multicolumn{2}{|c|}{ Not Dermatitis } & \multirow{2}{*}{ OR } & \multirow{2}{*}{$\mathbf{p}$} \\
\hline & $\mathbf{n}$ & $\%$ & $\mathbf{n}$ & $\%$ & & \\
\hline \multicolumn{7}{|l|}{ Personal Hygiene } \\
\hline Poor & 35 & 70 & 15 & 30 & 0.03 & $<0.001$ \\
\hline Good & 11 & 7.2 & 142 & 92.8 & & \\
\hline \multicolumn{7}{|l|}{$\begin{array}{l}\text { Perceived benefit (perso- } \\
\text { nal hygene) }\end{array}$} \\
\hline Low & 33 & 66 & 17 & 44 & 0.04 & $<0.001$ \\
\hline High & 13 & 8.5 & 140 & 91.5 & & \\
\hline \multicolumn{7}{|l|}{$\begin{array}{l}\text { Cues to action (personal } \\
\text { hygene) }\end{array}$} \\
\hline Low & 33 & 50 & 33 & 50 & 0.10 & $<0.001$ \\
\hline High & 13 & 9.5 & 124 & 90.5 & & \\
\hline \multicolumn{7}{|l|}{ Self-Efficacy } \\
\hline Low & 43 & 60.6 & 111 & 39.4 & 0.16 & $<0.001$ \\
\hline High & 3 & 21.4 & 46 & 78.6 & & \\
\hline \multicolumn{7}{|l|}{ Social Support } \\
\hline Low & 37 & 27.9 & 24 & 72.1 & 0.04 & $<0.001$ \\
\hline High & 9 & 6.1 & 133 & 93.9 & & \\
\hline \multicolumn{7}{|l|}{ Perceived susceptibility } \\
\hline Low & 40 & 61.5 & 25 & 38.5 & 0.02 & $<0.001$ \\
\hline High & 6 & 1.4 & 132 & 98.6 & & \\
\hline \multicolumn{7}{|l|}{ Perceived severity } \\
\hline Low & 34 & 55.7 & 27 & 44.3 & 0.07 & $<0.001$ \\
\hline High & 12 & 8.4 & 130 & 91.6 & & \\
\hline \multicolumn{7}{|l|}{ PPE } \\
\hline Incomplete & 43 & 64.2 & 24 & 35.8 & 0.01 & $<0.001$ \\
\hline Complete & 3 & 2.2 & 133 & 97.8 & & \\
\hline \multicolumn{7}{|l|}{$\begin{array}{l}\text { Perceived benefits (PPE } \\
\text { use) }\end{array}$} \\
\hline Low & 37 & 54.4 & 31 & 45.6 & 0.06 & $<0.001$ \\
\hline High & 9 & 6.7 & 126 & 93.3 & & \\
\hline \multicolumn{7}{|l|}{ Cues to action (PPE use) } \\
\hline Low & 37 & 52.8 & 33 & 47.2 & 0.06 & $<0.001$ \\
\hline High & 9 & 6.8 & 124 & 93.2 & & \\
\hline \multicolumn{7}{|l|}{ Self-efficacy } \\
\hline Low & 38 & 55.8 & 30 & 44.2 & 0.05 & $<0.001$ \\
\hline High & 8 & 5.9 & 127 & 94.1 & & \\
\hline \multicolumn{7}{|l|}{ Social Support } \\
\hline Low & 42 & 33.1 & 85 & 66.9 & 0.11 & $<0.001$ \\
\hline \multirow{2}{*}{\multicolumn{7}{|c|}{ Education }} \\
\hline & & & & & & \\
\hline$<\mathrm{JHS}$ & 34 & 37.8 & 56 & 62.2 & 0.19 & $<0.001$ \\
\hline$\geq \mathrm{JHS}$ & 12 & 10.6 & 101 & 89.4 & & \\
\hline \multicolumn{7}{|l|}{ Age (years) } \\
\hline $15-35$ & 26 & 40.6 & 38 & 59.4 & 0.24 & $<0.001$ \\
\hline $36-65$ & 20 & 14.5 & 119 & 85.5 & & \\
\hline
\end{tabular}




\section{Path Analysis}

\section{a. Model Spesification}

The specification of the model would illustrate the influence between the variables to be examined. In this study, there were 15 measured variables, including personal hygiene, perceived benefit of, cues to action, self-efficacy, social support, perceived susceptibility, perceived severity, self efficacy, social support, education, and age.

\section{b. Model Identification}

1. Measured variables
2. Endogenous variable $: 9$

3. Exogenous variable Total of parameter $: 6$ $: 18$ $\mathrm{df}=$ number of measured variables $\mathrm{x}$ (number of measured variables +1 ) / 2 (endogenous variables + exogenous variables + number of parameters) $\mathrm{df}=15 \times(15+1) / 2-(9+6+18)$ $\mathrm{df}=87$. The result of the degree of freedom (df) is 87 which means that over identified or path analysis can be done.

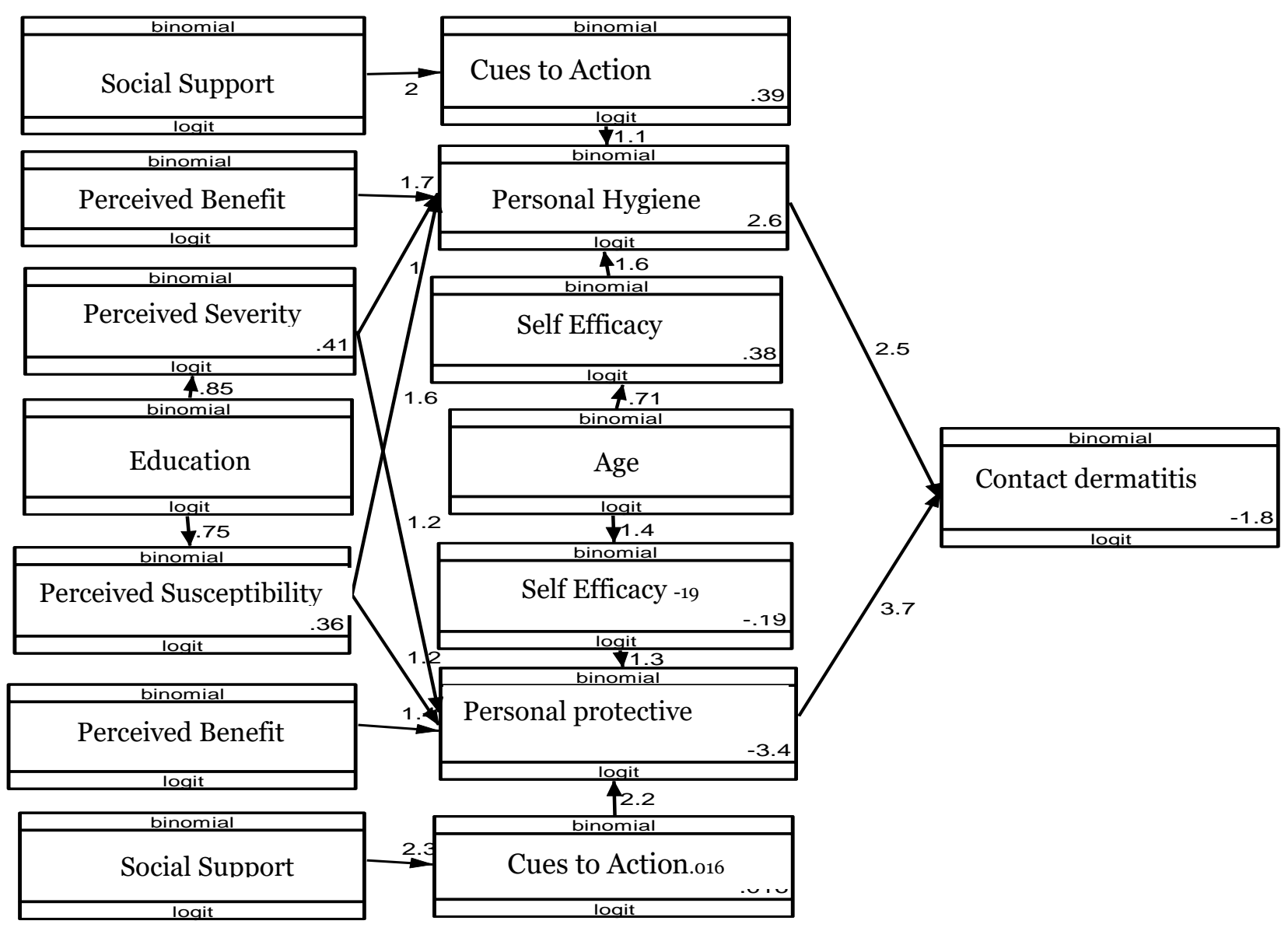

Figure 1. Structural Model of Path Analysis 
Journal of Health Promotion and Behavior (2019), 4(3): 198-211

https://doi.org/10.26911/thejhpb.2019.04.03.05

Table 3. The results of the path analysis of factors that affect the risk of contact dermatitis on scavengers

\begin{tabular}{|c|c|c|c|c|c|c|}
\hline \multirow{2}{*}{\multicolumn{3}{|c|}{ Variables }} & \multirow{2}{*}{$\mathbf{b}$} & \multicolumn{2}{|c|}{ CI 95\% } & \multirow{2}{*}{$\mathbf{p}$} \\
\hline & & & & \multirow{2}{*}{ Lower Limit } & \multirow{2}{*}{ Upper Limit } & \\
\hline \multicolumn{5}{|l|}{ Direct Effect } & & \\
\hline \multirow[t]{2}{*}{ Contact Dermatitis } & $\leftarrow$ & Personal Hygiene & 4.58 & 1.42 & 3.55 & $<0.001$ \\
\hline & $\leftarrow$ & $\begin{array}{l}\text { Personal Protective } \\
\text { Equipment }\end{array}$ & $5 \cdot 52$ & 2.38 & 5.01 & $<0.001$ \\
\hline \multicolumn{7}{|l|}{ Indirect Effect } \\
\hline \multirow[t]{4}{*}{ Personal Hygiene } & $\leftarrow$ & $\begin{array}{l}\text { Perceived } \\
\text { Susceptibility }\end{array}$ & 2.63 & 0.40 & 2.76 & 0.009 \\
\hline & $\leftarrow$ & Perceived Severity & 1.77 & -0.10 & 2.13 & 0.076 \\
\hline & $\leftarrow$ & Perceived Benefit & 3.03 & 0.59 & 2.78 & 0.002 \\
\hline & $\leftarrow$ & Cues of Action & 1.97 & 0.00 & 2.27 & 0.049 \\
\hline Cues to action & $\leftarrow$ & Social Support & 3.70 & 0.95 & 3.09 & $<0.001$ \\
\hline Personal Hygiene & $\leftarrow$ & Self Efficacy & 2.65 & 0.40 & 2.70 & 0.008 \\
\hline Self Efficacy & $\leftarrow$ & Age (15-35 years) & 2.21 & 0.08 & 1.33 & 0.027 \\
\hline \multirow{5}{*}{$\begin{array}{l}\text { Personal Protective } \\
\text { Equipment }\end{array}$} & $\leftarrow$ & Perceived & & & 236 & 0046 \\
\hline & & Susceptibility & 1.99 & 0.02 & 2.30 & \\
\hline & $\leftarrow$ & Perceived Severity & 1.97 & 0.00 & 2.34 & 0.048 \\
\hline & $\leftarrow$ & Perceived Benefit & 2.45 & 0.27 & 2.49 & 0.014 \\
\hline & $\leftarrow$ & Cues of Action & 3.96 & 1.09 & 3.24 & 0.001 \\
\hline Cues to action & $\leftarrow$ & Social Support & 5.23 & 1.42 & 3.12 & $<0.001$ \\
\hline $\begin{array}{l}\text { Personal Protective } \\
\text { Equipment }\end{array}$ & $\leftarrow$ & Self Efficacy & 2.08 & 0.70 & 2.43 & 0.038 \\
\hline Self Efficacy & $\leftarrow$ & Age (15-35) & 4.23 & 0.72 & 1.98 & $<0.001$ \\
\hline $\begin{array}{l}\text { Perceived } \\
\text { Susceptibility }\end{array}$ & $\leftarrow$ & Education & 2.46 & 0.15 & 1.34 & 0.014 \\
\hline $\begin{array}{l}\text { Perceived Severity } \\
\text { N Observation }=20 \\
\text { Log likelihood }=-86\end{array}$ & $\leftarrow$ & Education & 2.73 & 0.24 & 1.46 & 0.006 \\
\hline
\end{tabular}

The risk of contact dermatitis was directly and positively affected by poor personal hygiene and incomplete use of PPE. The risk of contact dermatitis was affected indirectly and positively by the perceived benefits of personal hygiene and low PPE, the originator of individual hygiene actions and low PPE, self-efficacy of personal hygiene and low PPE, social support of personal hygiene and low PPE, low perceived vulnerability, low perceived severity, <Middle school education, and age 15-35 years old.

Scavengers who have poor personal hygiene have contact dermatitis by 4.58 units higher than scavengers who have good personal hygiene $(b=4.58 ;$ CI95\% $=1.42$ to 3.55; $\mathrm{p}<0.001$ ).

Scavengers who did not use complete PPE would suffer from contact dermatitis by 5.52 units higher than scavengers who use full PPE (b=5.52; CI95\%= 2.38 to 5.01; $\mathrm{p}<0.001$ ).

Scavengers with low perceived susceptibility were not good in carrying out personal hygiene and the risk of experiencing contact dermatitis was 2.63 units higher than scavengers with high perceived susceptibility $(b=2.63$; CI95\% $=0.40$ to $2.76 ; p=$ 0.009).

Scavengers with low perceived susceptibility were not good in carrying out perso- 
nal hygiene and the risk of experiencing contact dermatitis was 1.99 units higher than scavengers with high perceived susceptibility $(\mathrm{b}=1.99$; CI95\% $=0.02$ to $2.36 ; \mathrm{p}=$ 0.046).

Scavengers with low perceived severity were not good in carrying out personal hygiene and the risk of experiencing contact dermatitis was 1.77 units higher than scavengers with high perceived severity $(b=$ 1.77; CI95\%= 0.10 to $2.13 ; \mathrm{p}=0.076$ ).

Scavengers with low perceived severity using incomplete PPE and the risk of experiencing contact dermatitis was 1.97 units higher than scavengers with high perceived severity $\quad(b=1.97 ; \mathrm{CI} 95 \%=0.00$ to 2.34; $\mathrm{p}=0.048$ ).

Scavengers who have low perceived benefit were not good in carrying out personal hygiene and the risk of experiencing contact dermatitis was 3.03 units higher than scavengers who have high perceived benefits $(b=3.03$; CI95\% $=0.59$ to $2.27 ; \mathrm{p}=$ 0.002).

Scavengers with low perceived benefit using incomplete PPE and the risk of experiencing contact dermatitis was 2.45 units higher than scavengers with high perceived benefit $(b=2.45 ;$ CI95\% $=0.27$ to $2.49 ; \mathrm{p}=$ 0.014).

Scavengers with low cues to action in performing personal hygiene and the risk of experiencing contact dermatitis was 1.97 units higher than scavengers with high cues to action $(b=1.97 ; \mathrm{CI} 95 \%=0.00$ to $2.27 ; \mathrm{p}$ $=0.049$ ).

Scavengers with low cues to action using incomplete PPE and the risk of experiencing contact dermatitis was 3.96 units higher than scavengers with high cues to action $(b=3.96 ;$ CI95\% $=1.09$ to $3.24 ; \mathrm{p}=$ o.001).

Scavengers with low self efficacy were not good in carrying out personal hygiene and the risk of experiencing contact derma- titis was 2.65 units higher than scavengers with high self efficacy $(b=2.65$; CI95\%= 0.40 to; $2.70 \mathrm{p}=0.008$ ).

Scavengers with low self efficacy using incomplete PPE and the risk of experiencing contact dermatitis was 2.08 units higher than scavengers with high self efficacy $(b=$ 2.08; CI95\%= 0.70 to 2.43; $\mathrm{p}=0.038$ ).

Scavengers with low social support in performing personal hygiene and the risk of experiencing contact dermatitis was 3.70 units higher than scavengers with high social support $(b=3.70 ;$ CI95\% $=0.95$ to 3.09; $\mathrm{p}=0.001$ ).

Scavengers with low social support using incomplete PPE and the risk of experiencing contact dermatitis was 5.23 units higher than scavengers with high social support $(b=5.23$; CI95\% $=1.42$ to $3.24 ; \mathrm{p}=$ o.001).

Scavengers with education $<$ JHS have low perceived susceptibility so that they were not good in implementing personal hygiene and were incomplete in using PPE and the risk of experiencing contact dermatitis was 2.46 units higher than scavengers with education $\geq$ JHS ( $b=2.46$; CI95\%= 0.15 to $1.34 ; \mathrm{p}=0.014$ ).

Scavengers who were $<$ JHS have low perceived severity so that it was not good in carrying out personal hygiene and incomplete in using PPE and the risk of experiencing contact dermatitis was 2.73 units higher than scavengers who were $\geq$ JHS ( $b=$ 2.73; CI95\%= 0.24 to $1.46 ; \mathrm{p}=0.006$ ).

Scavengers who were 15-35 years old have low self-efficacy so that they were not good in carrying out personal hygiene and the risk of experiencing contact dermatitis was 2.21 units higher than scavengers who were 36-65 years old $(b=2.21$; CI95\% $=0.08$ to $1.33 ; \mathrm{p}=0.027$ ).

Scavengers who were 15-35 years old have low self-efficacy so that they were not good in carrying out personal hygiene and 
Journal of Health Promotion and Behavior (2019), 4(3): 198-211

https://doi.org/10.26911/thejhpb.2019.04.03.05

the risk of experiencing contact dermatitis was 4.23 units higher than scavengers who were $36-65$ years old $(b=4.23$; CI95\% $=0.72$ hingga 1.98; $\mathrm{p}=0.038$ ).

\section{DISCUSSION}

1. The Direct Effect of Personal Hygiene on the Risk of Contact Dermatitis

The analysis showed that the risk of contact dermatitis had a direct effect on personal hygiene. The effect was statistically significant with a path coefficient of 4.58 and a $p$ value of $<0.001$. Scavengers who were not good at carrying out personal hygiene would experience contact dermatitis by 4.58 units higher than scavengers who were good at carrying out personal hygiene.

The result of this study was in line with Campbell et al. (2017) who states that there was a relationship between individual hygiene and irritant contact dermatitis, logistic regression test obtained $\mathrm{p}$ value $=$ 0.054. Scavengers have the risk of being exposed to dust, chemicals, heat, toxic elements and so on. Implementing personal hygiene properly and maintaining clean PPE was an effort to prevent primary contact dermatitis due to work (Zolnikov et al., 2018; Adisesh et al., 2013).

\section{The Direct Effect of Personal Pro- tective Equipment (PPE) on the Risk of Contact Dermatitis}

The analysis showed that the risk of contact dermatitis had a direct effect on PPE. The influence was statistically significant with a path coefficient of 5.52 and a $p$ value of $<0.001$. Scavengers who use incomplete PPE have the risk of developing contact dermatitis by 5.52 units higher than scavengers that use complete PPE.

This study was in line with Bhoyrul et al. (2019) who states that subjects who did not use PPE had contact dermatitis by 63.4\%. Avoiding allergens and irritants was an effort to avoid contact dermatitis. PPE was one of the ways to prevent contact dermatitis from exposure to irritants or allergens in the workplace (Johnston et al., 2017; Otaibi et al., 2015 ).

\section{The Indirect Effect of Perceived Susceptibility on the Risk of Con- tact Dermatitis}

The analysis showed that perceived susceptibility had an indirect effect on the risk of contact dermatitis through personal hygiene and PPE. The influence of individual hygiene was statistically significant with a path coefficient of 2.63 and $p=0.009$ and the effect of using PPE was statistically significant with a path coefficient of 1.99 and $p$ $=0.046$. Scavengers with low perceived susceptibility are not good in carrying out personal hygiene so that the risk of experiencing contact dermatitis was 2.63 units higher than scavengers with high perceived susceptibility and scavengers with low perceived susceptibility did not use complete PPE so the risk of experiencing contact dermatitis was 1.99 units higher than scavengers with high perceived susceptibility.

A study of Siswandwika et al. (2017) stated that there was an effect between perceived susceptibility to individual hygiene with a value of $\mathrm{p}<0.001$. Perceived susceptibility was a belief that someone would suffer from certain diseases, so that someone changed their behavior to avoid the disease. The results of the study of Wright et al. (2019) explained the positive correlation between perceived susceptibility to compliance with PPE use.

\section{The Indirect Effect of Perceived Severity on the Risk of Contact Dermatitis}

The analysis showed that perceived severity had an indirect effect on the risk of contact dermatitis through personal hygiene and PPE. The value of the path coefficient of the individual hygiene was 1.77 and the value of 
$\mathrm{p}=0.076$ and the influence of PPE was statistically significant with a path coefficient of 1.97 and a value of $p=0.048$. Scavengers with low perceived severity were not good in carrying out personal hygiene and were incomplete in using so the risk of experiencing contact dermatitis was 1.77 units higher than scavengers with high perceived severity. Scavengers with low perceived severity used incomplete PPE so that the risk of experiencing contact dermatitis was 1.97 units higher than scavengers with high perceived severity.

A study of Siswandwika et al. (2017) stated that there was an effect of perceived severity on personal hygiene. Perceived severity was a person's belief about the level of illness or the seriousness of the disease. The result of a study done by Wright et al. (2019) showed that there was an effect between perceived severities of compliance with the use of PPE.

\section{The Indirect Effect of Perceived Be- nefit on the Risk of Contact Derma- titis}

The results of the analysis showed that perceived benefits has an indirect effect on the risk of contact dermatitis through personal hygiene and PPE. The influence of individual hygiene was statistically significant with a path coefficient of 3.03 and $p=0.002$. Scavengers with low perceived benefit were not good in carrying out personal hygiene and the risk of experiencing contact dermatitis was 3.03 units higher than scavengers with high perceived benefit. The effect was statistically significant with a path coefficient of 2.45 and $\mathrm{p}=0.014$. Scavengers with low perceived benefit would use incomplete PPE and the risk of experiencing contact dermatitis was 2.45 units higher than scavengers with high perceived benefit.

A study of Siswandwika et al. (2017) stated that there was a direct and positive effect of perceived benefit on personal hy- giene as disease prevention. The perceived benefit was confidence in taking disease prevention measures and self-protective measures to reduce disease vulnerability. Sari et al. (2018) stated that there was an effect between perceived benefits on healthy behavior as disease prevention.

\section{The Indirect Effect of Cues to action on the Risk of Contact Dermatitis}

The results of the analysis showed that the trigger for action had an indirect effect on contact dermatitis through personal hygiene and PPE. The effect through personal hygiene was statistically significant with a path coefficient of 1.97 and $p=0.049$. Scavengers with low cues to action were not good at carrying out personal hygiene and the risk of experiencing contact dermatitis was 1.97 units higher than scavengers with high cues to action. Influence through the use of PPE with a path coefficient of 3.96 and $\mathrm{p}<0.001$. Scavengers with low-cues to action would use incomplete PPE by 3.96 units higher than scavengers with high-cues to action so that the risk of having contact dermatitis.

Agustin et al. (2018) stated that there was a positive effect on the originator of actions on the adherence to healthy behaviors as disease prevention. Research by Wright et al. (2019) shows the influence of the originator of actions on the use of PPE. The originator of action was a factor that drived a person to make decisions and improve healthy behavior influenced by social and environmental (Siswandwika, 2017).

\section{The Indirect Effect of Self Efficacy on the Risk of Contact Dermatitis}

The results of the analysis showed that selfefficacy has an indirect and positive effect on the risk of contact dermatitis through personal hygiene and PPE. The effect on individual hygiene was statistically significant with a path coefficient of 2.65 and $\mathrm{p}=$ 
0.008. Scavengers with low self-efficacy were not good in carrying out personal hygiene, so the risk of experiencing contact dermatitis was 2.65 units higher than scavengers with high self-efficacy. The influence on PPE was statistically significant with a path coefficient of 2.08 and a $p$ value of 0.038 . Scavengers with low self-efficacy would use incomplete PPE so that the risk of experiencing contact dermatitis was 2.08 units higher than scavengers with high selfefficacy.

The results of a study done by Siswandwika et al. (2017) stated that there was a positive effect of self-efficacy on personal hygiene as disease prevention. Research by Sari et al. (2018) stated that there was a direct effect between self-efficacy on healthy behavior as disease prevention. Self-efficacy was a belief in someone's own ability to perform healthy behaviors referring to an individual's perception of changes in health behavior (Arisa et al., 2017).

\section{The Indirect Effect of Social Sup- port on the Risk of Contact Derma- titis}

The result analysis showed that social support has an indirect and positive effect on the risk of contact dermatitis through the originator of actions to carry out individual hygiene and use of PPE. Scavengers with low social support were not good in carrying out personal hygiene, therefore, the risk of experiencing contact dermatitis was 3.70 units higher than scavengers with high social support. Scavengers with low social support using incomplete PPE and the risk of having contact dermatitis was 5.23 units higher than scavengers with high social support.

Christopher et al. (2014) stated that there was a positive relationship between social support and healthy behavioral intentions. The interaction of co-workers or families who live together helped to improve healthy behavior. Social support social, psychological and economic assistance was a moderator of behavior change (Lee et al., 2017; Albayrak et al., 2018).

\section{The Indirect Effect of Education on the Risk of Contact Dermatitis}

The analysis showed that education has an indirect effect on the risk of contact dermatitis through perceived susceptibility of the scavenger to carry out personal hygiene and using PPE. Scavengers with $<$ JHS education were not good in implementing personal hygiene and were incomplete in using PPE so that the risk of experiencing contact dermatitis was 2.46 units higher than that of scavengers who were $\geq J H S$. The analysis showed that education has an indirect and positive effect on the risk of contact dermatitis through the perceived severity of scavengers for carrying out personal hygiene and using PPE. The effect of education on peRceived severity was statistically significant with a path coefficient of 2.73 and $\mathrm{p}=$ o.oo6. Scavengers who were $<$ JHS were not good in implementing personal hygiene and were incomplete in using PPE so the risk of experiencing contact dermatitis by 2.73 units higher than scavengers who were $\geq$ JHS.

Thirarattanasunthon et al. (2012) stated that $55 \%$ of scavengers with elementary school education who were not disciplined in using PPE experienced several illnesses while working. Scavengers with low levels of education experience health risks related to employment. Education influenced someone's mindset in healthy behavior (Ren et al., 2018).

\section{The Indirect Effect of Age on the Risk of Contact Dermatitis}

The results of the analysis showed that ages 15-36 years old have an indirect and positive effect on personal hygiene and PPE through self-efficacy. Scavengers aged 15-36 years old were not good in carrying out per- 
sonal hygiene and the risk of experiencing contact dermatitis was 2.21 units higher than scavengers aged $36-65$ years old. The effect on PPE was statistically significant. Scavengers aged 15-35 years old were prone to not using complete PPE and the risk of having contact dermatitis was 4.23 units higher than scavengers who were 56-65 years old.

Thirarattanasunthon et al. (2012) stated that most scavengers did not use PPE. The average age of scavengers in TPA was 15 years old. The older the age, the level of ability and maturity of a person would be more mature in thinking. Older age would avoid the risk than young age (Sproten et al., 2018).

\section{AUTHOR CONTRIBUTION}

Niken Kartika Sari played a role in collecting and analyzing research data. Setyo Sri Rahardjo examined the conceptual framework and research methodology. Vitri Widyaningsih examined the data analysis and interpretation of the results of the analysis.

\section{SOURCE OF FUNDS}

This study used personal costs from the main author.

\section{CONFLICT OF INTEREST}

The authors did not have any conflict of interest.

\section{ACKNOWLEDGEMENT}

We would like to thank to Putri Cempo TPA who has helped the process of this study and respondents who have participated and were willing to become research subjects.

\section{REFERENCES}

Adisesh A, Robinson E, Nicholson PJ, Sen D, Wilkinson M (2013). U.K. Standards of care for occupational contact derma- titis and occupational contact urticaria. Br J Dermatol. 168(6): 1167-1175. https://doi.org/10.1111/bjd.12256

Agustin DA, Prasetyo AA, Murti B (2018). A path analysis on adherence to antiretroviral therapy among HIV/ AIDS patients at Dr. Moewardi Hospital, Surakarta using health belief model. J Health Promot Behav. 03(01): 48-55. https://doi.org/10.26911/thejhpb.2018.03.01.05

Albayrak S, Çakır B, Kılınç FN, Vergili Ö, Erdem Y (2018). Reliability and validity study of the Turkish version of child and adolescent social support scale for healthy behaviors. Asian Nurs Res. 12(4): 273-278. https://doi.org/10.1016/j.anr.2018.10.004

Arisa A, Soemanto RB, Rahardjo SS (2017). The effect of internal and external factors on preventive reproductive health behaviors in adolescents, in Banjarmasin, Kalimantan, J Health Promot Behav. 2(4): 350-358. https://doi.org/10.26911/thejhpb.2017.02.04.07

Aunger R, Greenland K, Ploubidis G, Schmidt W, Oxford J, Curtis V (2016). The determinants of reported personal and household hygiene behaviour: a multi country study. Plos One. 14(8): 1-35. https://doi.org/10.1371/journal.pone.0159551

Bhoyrul B, Lecamwasam K, Wilkinson M, Latheef F, Stocks SJ, Agius R, Carder $M$ (2019). A review of non-glove personal protective equipment-related occupational dermatoses reported to epiderm between 1993 and 2013. Contact Dermatitis. 8o(4): 217-221. https://doi.org/10.1111/cod.13177

Campbell K, Baker B, Tovar A, Economos E, Williams B, McCauley L (2017). The association between skin rashes and work environment, personal protective equipment, and hygiene practices am- 
Journal of Health Promotion and Behavior (2019), 4(3): 198-211

https://doi.org/10.26911/thejhpb.2019.04.03.05

ong female farmworkers. Workplace Health and Saf. 65(7): 313-321. https://doi.org/10.1177/2165079916671955

Carder M, McNamee R, Gittins M, Agius R (2017). Time trends in the incidence of work-related ill-health in the UK, 19962016: estimation from THOR surveillance data report to the UK health and safety executive (August): 1996-2016. Retrieved from http://www.hse.gov.uk/statistics/pdf/thortrends17.pdf

Christopher J, McKinley, Paul J, Wright (2014). Informational social support and online health information seeking: Examining the association between factors contributing to healthy eating behavior. Comput Human Behav. 37(2014): 107-116. http://dx.doi.org/10.1016/j.chb.2014.04.023

Dinas Lingkungan Hidup (2019). Monthly waste volume data of Surakarta City in 2017. Retrieved from http://dlh.surakarta.go.id/new/?pas\&id=24

Johnston GA, Exton LS, Mustapa MF, Slack JA, Coulson IH, English JSC, Bourke JF (2017). British association of dermatologists' guidelines for the management of contact dermatitis 2017. Br J Dermatol. 176(2): 317-329. https://doi.org/10.1111/bjd.15239

Lee LT, Bowen PG, Mosley MK, Turner CC (2017). Theory of planned behavior: social support and diabetes self-management. J Nurse Pract. 13(4): 265-270. https://doi.org/10.1016/j.nurpra.2016.07 .013

McKinley CJ, Wright PJ (2014). Informational social support and online health information seeking: examining the association between factors contributing to healthy eating behavior. Comput $\mathrm{Hu}-$ man Behav. 37: 107-116. https://doi.o$\mathrm{rg} / 10.1016 / \mathrm{j} . c h b .2014 .04 .023$

Novianingrum, Mulasari SA (2017). Characteristics of scavengers with skin disea- ses in Wukisari. Kemas. 13(2): 224-229. https://doi.org/.224-229.10.15294/kemas.v13i2.4729

Nyathi S, Olowoyo JO, Oludare A (2018). Perception of scavengers and occupational health hazards associated with scavenging from a waste dumpsite in Pretoria, South Africa. J Environ Public Health. 2018(9458156): 7. https://doi.org/http://dx.doi.org/10.1155/20189458156

Otaibi STA, Alqahtani HAM (2015). Management of contact dermatitis. J Dermatol. 1-6. https://doi.org/10.1016/j.jdds.2015.01.001

Pardiansyah R (2015). Association between personal protective equipment with contact dermatitis in scavengers. J Majority. 4(4): 80-87. Retrieved from https://www.semanticscholar.org/paper/association-between-personal-protective-equipment-pardiansyah/fdd14045f17b4f40ac29a3454deb257cd6c26a98

Permenaker (2010). Minister of manpower and transmigration of the Republic of Indonesia. 1-8.

Ren Y, Zhang Y, Castro CB, Loy JP (2018). Unhealthy consumption behaviors and their intergenerational persistence: the role of education. Chin J Popul Sci. 1-69 https://doi.org/10.1016/j.chieco.2018.08.004

Sari SAAY, Indarto D, Wijaya M (2018). Application of health belief model on preventive behaviors of patients with low back pain. J Health Promot Behav. 3(3): 192-198. https://doi.org/10.26911/thejhpb.2018.03.03.06

Silvestre MC, Dos RVMS (2018). Evaluation of the profile of inflammatory cytokines, through immunohistochemistry, in the skin of patients with allergic contact dermatitis to nickel in the acute and chronic phases. An Bras Dermatol. 93(6): 829-835. https://doi.org/10.1590- 
/abd1806-4841.20187126

Siswandwika HD, Murti B, Dharmawan R (2017). Biopshychosocial and economic determinants of personal hygiene in the prevention of diarrheal diseases in Sragen District, Central Java. J Health Promot Behav. 02(01): 1-14. https://doi.o$\mathrm{rg} /$ 10.26911/thejhpb.2017.02.01.01

Sproten AN, Diener C, Fiebach CJ, Schwieren C (2018). Decision making and age: factors influencing decision making under uncertainty. J Behav Exp Econ. 76: 43-54. https://doi.org/10.1016/j.socec.2018.07.002

Suryani ND, Martini, Susanto HS (2017) Comparison of risk factors for the incidence of irritant contact dermatitis from salt farmers and rice farmers in Kaliori District, Rembang Regency. JKM. 5(4):444-454. Retrieved from https://ejournal3.-

undip.ac.id/index.php/jkm/article/vie$\mathrm{w} / 18661$

Thirtarattanasunthon P, Siriwong W, Rob- son M, Borjan M (2012). Health risk

reduction behaviors model for scavengers exposed to solid waste in municipal dump sites in Nakhon Ratchasima Province, Thailand. Risk Manag Healthc. 5: 97-104. https://doi.org/10.2147/RMHP.S30707

Wright T, Adhikari A, Yin J, Vogel R, Smallwood S, Shah G (2019). Issue of compliance with use of personal protective equipment among wastewater workers across the southeast region of the United States. Int J Environ Public Health. 16(11): 1-18. https://doi.org/10.3390/ijerph16112009

Zolnikov TR, Silva RC, Tuesta AA, Marques CP, Cruvinel VRN (2018). Ineffective waste site closures in Brazil: a systematic review on continuing health conditions and ocupational hazards of waste collectors. Waste Manag. 80: 26-39. https://doi.org/10.1016/j.wasman.2018.08.047 